\title{
Operationalising the Rights Agenda: Participatory Rights Assessment in Peru and Malawi
}

\author{
James Blackburn, Mary Ann Brocklesby, Sheena Crawford and \\ Jeremy Holland
}

\section{Introduction}

Throughout the 1990s, debates about human rights and development increasingly converged. With a renewed focus on poverty reduction, international agencies have moved away from a narrow concern with the poverty line to attempt more directly to understand the underlying dynamics of poverty in any particular society or context. This shift has been supported by the increasing use of powerful analytical frameworks developed from theoretical work by Sen $(1981 ; 1997)$ on entitlements and capabilities, from the food security literature of the 1980s (Devereux and Maxwell 2001) and later work on vulnerability (Swift 1989; Moser 1998). Significantly, this has moved policy debates away from a focus on assessing and responding to needs, a process that in the past has not necessarily disturbed existing allocations of entitlements (Brocklesby and Crawford 2004a).

During the same period that development agencies have embraced these multidimensional analytical frameworks, human rights concerns have developed from a first-generation "negative" concern with protecting individual civil and political (CP) rights, to a broader and more developmental concern with ensuring economic, social and cultural (ESC) rights linked to poverty reduction goals. Among development agencies, the United Nations Development Programme (UNDP 2000) has been instrumental in pushing the rights and entitlements agenda, now widely reflected in development agency discourse (see Cornwall and NyamuMusembi, this issue). A more recent UN interagency statement (United Nations 2003) of common understanding stresses the need for development cooperation to contribute to the development of the capacities of "duty bearers" to meet their obligations and/or of rights holders to claim their rights (see Piron, this issue).

This convergence of discourse - the developmental approach to rights and the dynamic approach to poverty - enables development agencies in principle to engage with what Moore and Putzel (1999) call the "politics of poverty". The rights discourse politicises poverty analysis and refocuses attention on the institutions and processes that determine development outcomes. This presents a new set of challenges to development agencies that are not easily addressed. Important factors explaining the continued absence of a rights focus in poverty and policy debates are the language of rights and the politicised nature of rights assessment and fulfilment. This article, through a review of a continuing Department for International Development (DFID) initiative in Malawi and Peru - the Participatory Rights Assessment Methodologies (PRAMs) project - looks at the challenges facing donor agencies as they seek to operationalise a stated commitment to rights-based development. These experiences of assessing rights in practice draw attention to how rights are defined in particular contexts and how the effectiveness of rights in a particular context is mediated by existing power structures, which may be slow to change.

A focus on participatory rights-based assessment ties in with the growing trend towards participation in development processes (see below), with its emphasis on institutional engagement and change 
and on local ownership. By bringing a more specific rights and entitlements analytical framework, however, a participatory rights assessment approach politicises analysis, highlighting power relations and processes of exclusion and discrimination. Participatory rights assessments have the potential to identify both the institutional structures that define, interpret and implement rights as well as the political processes that define the channels through which citizens can contest their claims. The lessons learned from DFID's PRAMs initiative highlight both the potential of rights to address the structural causes of marginalisation, and also the complexity of implementing rights-based approaches.

\section{Rights, participation and institutional change}

First, it is useful to situate the emergence of rights assessments within wider concerns about more participatory and politicised approaches to development. In moving from poverty assessment to this approach, the role of national institutions and the need for institutional analysis takes on an added significance. Not only does rights-based development politicise development, but it builds in a strong action orientation linked to institutional accountability and transparency. Within this context, participation itself becomes politicised, echoing Gaventa and Valderrama's (1999) thesis on the evolution of community and political participation into what Lister (1998) describes as "citizenship participation":

Citizenship as participation can be seen as representing an expression of human agency in the political arena, broadly defined; citizenship as rights enables people to act as agents. (Lister 1998, cited in Gaventa and Valderrama 1999: 4)

Webster and Engberg-Pederson (2002) make a critical distinction between strategies of the poor to access directly assets and resources and those that seek to influence policy design and implementation in favour of redistributive equity. This second type of strategy, they argue, has important implications for the nature of participation, for empowerment of the poor and for the institutional basis of poverty and inequality. The success of this qualitatively different type of participation, however, is contingent upon the opening up of "political space" for engagement and change. Webster and Engberg-Pederson (op cit) conceive of three elements of political space for participation by the poor:

- institutional channels through which policy formulation and implementation can be accessed, controlled or contested by the poor;

- political discourses in which poverty and poverty reduction are significant issues; and

- social and political practices of the poor, which may be a basis for influencing decision making, agendas, policy and programme implementation, etc.

This conceptualisation of the constitution of political space is given operational focus by Moser and Norton (2001) in their analysis of the "channels of contestation", through which the poor can claim their rights in the context of a range of formal and informal "rights regimes", each with their own institutional structures. They define a rights regime as a system of rights which derive from a particular regulatory order or source of authority. These can overlap, for example through customary, religious and statutory law. Institutional structures are those that determine the definition, interpretation and implementation of key rights. The political process then defines the channels through which actors can contest claims and challenge institutional norms.

\section{Operationalising the discourse: participatory rights-based assessment}

Rights-based development, it seems, provides an operational commitment to a qualitatively different form of participation, in which citizens exercise their right to participate in challenging and changing the institutions that govern their lives. If this is the case then how might development agencies most effectively change their practice to make this approach work?

Certainly, elements of the donor community have arrived at a position of promoting process as the basis for rights-based development. For UNDP, rights are not an outcome of development but are integral to the development process:

human rights are not, as has sometimes been argued, a reward of development. Rather they are critical to achieving it. (UNDP 2000: iii) 
Similarly, the World Bank's World Development Report 2000/01 (World Bank 2000) marked a shift in emphasis on 'empowerment' through enhanced political participation of poor people, prompting greater efforts to articulate and categorise the forms of relations between citizen voice and duty bearer/service provider responsiveness. ${ }^{1}$

In its Target Strategy Paper, Realising Human Rights for Poor People, DFID (2000) outlines its commitment to a rights-based approach to development ${ }^{2}$ as the most effective means to achieving poverty reduction outcomes, measured by the Millennium Development Goals (see Shetty, this issue). ${ }^{3}$ Founded on values of active citizenship, democracy and accountability and equality and non-discrimination, the Target Strategy Paper builds its strategy on the three core principles of participation, inclusion and fulfilling obligation. Participation is central to the DFID strategy and means ensuring that the voices of the poor are heard as active citizens, rather than muted as passive beneficiaries. Recent studies, including the World Bank's series of Consultations with the Poor (Narayan et al. 2000), have revealed that local people, even those living under democratically elected governments, feel powerless, starved of information, unable to hold public duty bearers to account and lacking in influence over the key decisions which affect their lives. People's right to freedom of opinion and expression and their right to receive and impart information are widely threatened. DFID's position is that through participation, poor people, and not just local elites, are empowered to claim all their human rights.

In seeking to operationalise its Target Strategy Paper, one way forward for DFID was to develop an existing research instrument - the Participatory Poverty Assessment (PPA), but with greater focus on rights assessment and fulfilment. The PPA is an instrument that brings together participation and multidimensional poverty analysis. The "first generation" of PPAs in the early 1990s emphasised information extraction for donor evaluation through participation, with a variable emphasis on entitlements. "Second generation" PPAs emphasise more strongly national ownership of process and findings, tied to policy processes such as the Poverty Reduction Strategy Paper (PRSP), while emerging "third generation" PPAs stress greater local ownership, the "scaling up" of participation (from its roots in community development and project cycles), through direct interaction between policymakers and citizens and the need to identify political space for institutional change. The next section will examine two cases where participatory rights assessments have been used to build a picture of rights rooted in local realities and address the implications of these examples for donors seeking to implement rights-based approaches in their work.

\section{Two case studies}

The DFID PRAMs project is one response to the challenge of putting their rights agenda into practice (see Brocklesby and Crawford 2004b; CDS Swansea and Edinburgh Resource Centre 2002). The project aims to find ways of supporting governments, civil society and other social actors in understanding their rights and obligations and in creating the institutional change necessary to ensure participation, inclusion and obligation for all human rights for all people. The project aims to facilitate:

- people's own identification and assessment of their rights

- understanding and agreement between stakeholders of the obstacles poor people face in accessing those rights

- identification of actions to support governments and other duty bearers in the protection, promotion and realisation of human rights; and

- institutional change and the opening up of new channels of institutional engagement between citizens and duty bearers towards these ends.

The project is presently being piloted in partnership with DFID country desks in Malawi and Peru. In each case, the project initially identified a "political space" and associated institutional structures that determined the definition, interpretation and implementation of key rights in that space. In Malawi, the intervention is integrated within a broader education sector support programme and is focused on community participation in school management. In Peru, participatory rights-based assessment is embedded in a human rights programme, which disburses project funding and facilitates citizenship participation in local governance. These pilot initiatives are providing useful lessons for expanding participatory rights assessment into different institutional and policy contexts. 


\subsection{Case study 1: The Malawi Education Sector Support Programme}

The Malawi Education Sector Support Programme (ESSP) started in April 2001, designed by DFID to assist the Ministry of Education, Science and Technology (MoEST) to implement its policy framework. ESSP contracted the international nongovernmental organisation (NGO), CARE, through its Partnership in Capacity Building in Education (PACE) programme, to support its work towards school improvement and increased community participation in school management. PRAMs in Malawi is being promoted as the methodology to embed rights-based development in ESSP and to underpin the PACE school improvement planning process (see Crawford 2004). This process is being carried out in six pilot districts, with stakeholders at all levels participating in the development of school improvement plans. Plans are then put into operation and networks of local government and NGOs established and their capacity for rightsbased school improvement strengthened. The school improvement planning process addresses key rights linked to gender, HIV status, child-headed households, teacher-child relations, child-child abuse and community participation.

The participatory rights assessment process in Malawi builds on workshops that train district education officers, staff of other ministries, national NGO representatives and the PACE support team in the principles and practice of participatory and rights-based development for the school improvement planning process. Teams then work with communities and education sector stakeholders to develop and implement school improvement plans for local schools. To date, multisectoral District Education Support Teams have been trained in the six districts and have, in turn, carried out participatory school improvement planning in their districts. National discussions on lessons learned from this process have further informed policies for operationalising the National Strategy for Community Participation in Primary School Management and, it is hoped, will influence the development of a National Policy on Social Inclusion.

The participatory rights assessment process in Malawi has brought together people from all different levels in the Education system, from the Chief Education Advisor of the MoEST, District Commissioners (DCs) and District Education
Managers (DEMs), through Community Development Assistants (CDAs) and representatives of different groups in the communities, including the most marginalised individuals. People from different educational backgrounds, and with very different experiences and authority, have worked together in mixed teams to do participatory rights assessment in the school communities and build a school improvement plan with local people. It may seem a small thing, but in a hierarchical society where, traditionally, "big" men sit on chairs and women curtsey at their feet, the fact that the DC will take off his jacket and tie and sit on the ground with children, is a big change in the way things usually work. The top officials were very happy to be part of the team; drawing maps in the dust, singing songs and encouraging children to express their own hopes and expectations for better education. Children and adults alike talked with these officials as if they were just "ordinary people". Afterwards, everyone said that the experience had been enjoyable. The DEM from Ntcheu, for instance, said that he felt really bad that he had never had the opportunity to talk with the people in his constituency in this way before. He said he had learned so much and had previously had no idea about many of the problems and issues that were raised.

A particularly powerful method for generating a partnership approach to rights realisation was the use of social contracts. The participatory rights assessment teams facilitated the development of Social Contracts for School Improvement during the school community visits. Each interest group in the community initially drew up their own contract; they decided on what the community could expect from them in terms of putting school improvement into practice.

The groups made their contracts using the information and understanding they had built up during a Significant Change activity. Each group built a matrix to identify the most important school improvements needed and decide on the "who, what, why, where, when and how" for achievement of these improvements. The groups identified their responsibilities and agreed on a time-frame. They also thought about what could be expected from other groups. So, for example, the girls considered what their parents and the school management committee should do, as well as considering their own roles. At the end of the three-day visit, in the plenary meeting which everyone attended, each 
group presented its personal contract and then went through a process of negotiating and agreeing until we ended up with a Social Contract which brought together the whole school and village community.

The contracts themselves are quite simple; there was no great elaboration of detail. What was very important, though, was the fact that everyone committed themselves to particular roles and responsibilities and pledged themselves to these in a public forum. People, especially those who are normally marginalised from decision making, really valued the chance to express what they could offer, and to assist in determining what other people can be expected to do. People who held traditional decision-making roles did not feel threatened, but were quite surprised at the "sensible suggestions" coming from people they do not always listen to, like children and older women.

\subsection{Case Study 2: Human Rights for the Poor in Peru Programme}

PRAMs in Peru has successfully become embedded as a methodological component of the Human Rights for the Poor in Peru (HHRR) Programme, a DFID-funded programme which is being implemented by Oxfam Peru. The purpose of HHRR is to facilitate strategies which enable the poor to realise their human rights, supported by civil society, government and the international community. In doing so, the programme will help achieve two goals: the increased responsiveness of government and civil society in Peru to the human rights realisation strategies of the poor; and the mainstreaming of a rights-based approach to development within the international community in Peru.

One major objective of the programme is the systematic use of participatory methodologies. These methodologies are being developed to assess rights and local strategies to claim them (in part through the design and sponsorship of Programme sub-projects and in part through associated broader institutional change); and to assess programme impact. The HHRR has identified six local NGO partners that will work within the target project areas. These NGOs are already active in strengthening local organisations and in building rights awareness among local people and their role is to facilitate local assessment of priorities and design of sub-projects for funding through the HHRR and to establish coridores, or communication channels, between the participating geographical departments. Each NGO has understood PRAMs in a different way and are developing quite different processes and experiences which eventually will be fed back into national learning and PRAMs development.

One of these NGOs is ADEAS QULLANA, ${ }^{5}$ a small NGO that has long been rooted in Santo Tomás in southern Cusco, a remote rural Quechuaspeaking area, one of the poorest of Peru (see Blackburn 2004). The general opinion of the ADEAS team members is that 'we were doing PRAMs before PRAMs; we just didn't have a name for it'. ${ }^{6}$ In extending its experience of community planning and training to participatory rights assessment, ADEAS has learned the importance of context. Political space in any context is already powerinfused and what PRAMs can realistically achieve will vary according to the characteristics of the institutions in each context. In some contexts, local power holders little used to being challenged have traditionally held sway over local politics and intend to control the new spaces for citizen participation in planning and reviewing local public expenditure opened up by recent legislation, in particular the mesas de concertación (municipal planning fora) and local coordinating councils. In other contexts, there has been a greater openness to a partnership approach that involves collective rights assessment and action for change.

The PRAMs process followed by ADEAS has been to facilitate workshops with a partnership of actors and organisations to raise awareness about rights, identify obstacles to their realisation and formulate "rights realisation" initiatives. ADEAS then stays with this process through to implementation and monitoring of impact, with lessons learned documented for future practice.

ADEAS has encouraged participants to use a range of participatory methods, including card sorting and problem tree analysis, with dramatisation particularly powerful for assessing the rights context and barriers to rights fulfilment. The uses of drama in conscientization are well known. What is noteworthy in this case, is that ADEAS made good use of dramatisation to facilitate systematic reflection by participants on the link between problems and rights. More important than the drama itself, say ADEAS facilitators, is the space for discussion and interpretation afterwards. Clearly, ADEAS, as an NGO experienced in alternative 
education, has built up a considerable expertise in the use of drama to raise awareness and in this case it was evident that they successfully adapted the tool to the requirements of PRAMs. Indeed, while there is scope for expansion in the use of methods, particularly in using Participatory Learning and Action (PLA)-type tools for institutional assessment, the importance of developing and using tools in context rather than being subjected to a perceived PLA method "colonisation" was strongly emphasised from the beginning.

PRAMs in Peru is being promoted as an empowering process which brings with it the recognition that ensuring inclusion of the poorest and most marginal will take time. Partners are committed to a lengthy process because they are committed to ensuring that inclusion, participation and obligation occurs in practice. They are also committed to the local identification of rights in context and to linking assessment of those rights to local forms of action.

Follow-up stages planned at time of writing will involve the local NGOs providing technical support to community-based organisations. This support is aimed at helping those organisations develop partnerships with different organisations in government and civil society and to develop small proposals centred on realising their rights. The national HHRR programme will fund these proposals. Once one cycle of identification, capacity building and implementation is complete a participatory evaluation process aimed at disseminating lessons learnt and mainstreaming the approach throughout Peru will take place.

\section{Emerging lessons}

The DFID PRAMs programme is now drawing to a close. PRAMs has for the most part achieved its aims. The project has demonstrated that a rightsbased approach does work and can achieve results. When rights-based approaches and methods are used, people are empowered. Duty bearers feel more secure in their work and claim holders feel able to join in decision making and share in roles and responsibilities for their own development. This leads to greater commitment and investment from all stakeholders. The project has also identified the challenges and pitfalls associated with this approach and offered a range of potential strategies, entry points and methods for operationalising rights-based development. These challenges are not always new, but bear repeating in what is a relatively new operational context. While a projectised approach to institutional transformation must be necessarily modest in ambition, it seems that there are several elements behind the success or failure of donor-supported institutional change initiatives such as PRAMs. Here we consider emerging lessons as a contribution to the growing debate on mainstreaming participatory rights-based assessment, not just within DFID, but also with partner organisations.

\subsection{Rights-based development politicises a process approach}

In moving from poverty assessment to more politicised rights assessment, the role of national institutions and the need for institutional analysis takes on an added significance. Not only does rightsbased development politicise development, it also builds in a strong action orientation linked to institutional accountability and transparency. Rightsbased development prompts an operational commitment to a qualitatively different form of participation, in which citizens exercise their right to participate in challenging and changing the institutions that govern their lives. The focus of attention and intervention is on the relationships, institutions and processes, which determine development outcomes or change. This requires a process approach that embeds lesson learning from day one.

The ambition of participatory rights assessment to provoke institutional change should bring with it a recognition that conflict generation is also likely, particularly in local contexts where traditional power holders are likely to react adversely to rightsbased approaches which challenge them. Future participatory rights assessment should pay more attention to the probable need for conflict management strategies and methodologies on the part of those facilitating the process.

\subsection{Rights-based development addresses structural inequality}

PRAMs was only operational when a focus on the causes of inequality became central to the way of working. Inclusion, one of the main tenets of rightsbased development, brings with it an understanding that building knowledge and capacity to enable people to claim their rights requires understanding of the barriers which stop certain groups of people 
exercising their rights and participating in decisions which affect their lives. Because such structural inequalities deny certain groups of people such as women, children or minority groups access to their rights, rights-based development is directly concerned with power relationships. Operationally this focuses attention on building the capacity and voice of poor and marginalised people, changing existing structures and ensuring institutional accountability.

\subsection{Rights-based participation means changing institutional relationships}

There is, within development agencies (national government hierarchies, the donor community and civil society organisations), a tendency to manage participatory processes closely. Participation tends to be seen as a technical method of programme intervention rather than as a political methodology of empowerment. These two quite distinct responses lie on a continuum between interventions: those which work within existing structures and those that seek to transform structures (Mwasaru, this issue). In implementing PRAMs, it was clear that the key entry point for all organisations was in recognising the transformative institutional foundations of rights-based approaches. Rightsbased development demands a commitment to change the way representatives of the state and civil society organisations work with, and respond to, the demands of citizens. As well as between individuals and institutions, this change is also about change within and between individuals. It is the difference between "doing" participation and "being" participatory. This does not mean imposing an artificial participatory process. Rather, it is building on existing forms of participation using transparent, intentionally transforming practices. The PRAMs process demonstrated that this requires a close reading of local development processes and institutional relationships.

\subsection{Understanding the rights environment is key to rights-based development distinctiveness}

It is essential that rights-based development builds a basic understanding of the wider rights environment in context. This includes understanding the formal and informal local rights systems within which people live their lives and develop their own concepts and capacities to address rights issues (Nyamu-Musembi, this issue). Here it is useful to distinguish between a formalist and a pluralist approach to rights-based development. A formalist approach refers continually to rights standards as the baseline and defines good practice through the delivery of minimum standards in goods and services as a right. A pluralist approach emphasises the way that people and structures relate to each other. These check that, in any given development intervention, all obligations and agreements have been met. In particular, powerful people and institutions are held accountable to fulfil their responsibilities to those with less power.

The PRAMs process suggests strongly that international rights-based instruments and local legal rights frameworks and institutions underpin our work, but do not necessarily form the entry point through which rights-based development can be initiated and implemented. This is because while rights-based development is facilitated through a clear "hook" within a programme, it will only emerge as a distinct and innovative approach to development if it is embedded within the wider perspective that attention to the rights environment brings with it. The interrelated nature of rights demands this focus so that operationally, attention is systematically given to working at all levels of society from individuals through communities, to politicians and national institutions.

\subsection{The role of donor institutions matters}

The experience with PRAMs highlighted the inherent contradictions between a politicised institutional change process and the technical and bureaucratic mode of operation that characterises some donor institutions. The politicisation means that representatives of donor institutions must forgo a position of neutrality or supervision and become part of the messier and less manageable process of transformative change. The success of PRAMs in Malawi and Peru was due in large part to the flexibility and sensitivity of the DFID staff involved. Individual "champions" of the project were able to identify political space for participatory rights-based assessment and play a proactive role in facilitating the process in each case.

\subsection{Participatory rights assessment should not be tool-driven}

This may seem obvious, but it was not the original premise of PRAMs. An early assumption of the project was that a "toolkit" of methods could help 
facilitate and engender rights-based practice. During the process of implementing the project, an understanding of what was meant by rights-based development and how PRAMs could take this forward, deepened and changed. The tools and methods emerge from the process of multistakeholder commitment to, and exploration of, the wider process of rights-based development; not, as was first assumed, the other way round.

\subsection{Facilitating skills are more important than tools}

In the process of initiating and implementing PRAMs, the teams innovated and adapted around existing participatory assessment tools. As such, PRAMs has demonstrated that rights-based development builds on good practice, but as is true in all process-led approaches, good practice can be undermined by the way the tools are used. Promotion of a rights-based development process depends on the manner of facilitation: facilitators of participatory rights assessment need a strong grounding in rights-based development allied with highly developed capacities for innovative, flexible participatory work with stakeholders at all levels.

These insights from the PRAMs case studies

\section{Notes}

1. The concepts of "voice" and "responsiveness" are discussed further in Goetz and Gaventa (2001).

2. See also Häusermann (1998), background discussion paper.

3. The Millennium Development Goals were approved by the General Assembly of the United Nations in 2000. They represent a continuation of the International Development Targets codified by the Development Assistance Committee of the OECD in 1996. See Shetty (this issue).

4. Interestingly, the Malawi stakeholders insisted on changing the name from PRAMs to PRAss (Participatory Rights

\section{References}

Blackburn, J., 2004, 'Owning and operationalising the PRAMs concept in the HRP Programme, Peru: a case study of ADEAS QULLANA, Cusco', Consultancy Report, 7 May

Brocklesby, M.A. and Crawford, S., 2004a, 'Rightsbased development: guidelines for highlight a number of lessons that can be applied more broadly as DFID and other donors continue to refine and develop their approach to rightsbased development. What is encouraging about the experience of participatory rights assessment in Malawi and Peru is that there is preliminary evidence that a rights-based approach adds significant value to more generic and long-standing "people-centred" development initiatives. Rights in the PRAMs experience were not perceived as a "tag-on", disconnected from people's primary concerns. On the contrary, they were very much the central issue: 'It's what makes this project different from the others', said a teacher in Haquira, Peru, voicing the predominant view. 'PRAMs is different because we've realised it's not just a project, it's all about us'.

The dominant perception, articulated by many with considerable emotion and conviction, is that projects without an explicit rights dimension engender conformism and passive acceptance. In contrast, PRAMs would seem to facilitate ownership. But more than that, PRAMs arouses personal commitment. As another PRAMs participant put it: 'once you understand - really understand - that you have rights, everything changes'.

Assessment), reflecting an increased level of ownership of the process. PRAss could not have come about without the dedication and commitment of all participants, particularly the MoEST, Norman Tembo and his team in CARE and Chris Cosgrove (until recently) in DFIDMalawi.

5. We are very grateful to the ADEAS QULLANA team for facilitating a recent review of their work on the HHRR Programme.

6. It is intriguing that the English abbreviation PRAMs continues to be used by ADEAS (and indeed other HHRR partners), even though no one knows what the actual English words are. A Spanish equivalent remains to be found.

implementation', Draft Paper prepared for the Department for International Development, June Brocklesby M.A. and Crawford, S., 2004b, Operationalising the Rights Agenda: DFID's Participatory Rights Assessment Methodologies (PRAMs) Project, paper prepared for the Department for International Development, March 
CDS Swansea and Associates and Edinburgh Resource Centre Ltd, 2002, 'PRAMs: linking participation and institutional change', Draft Background Working Paper on the Participatory Rights Assessment Methodologies (PRAMs) Project, prepared for the Department for International Development, 31 October

Crawford, S., 2004, 'Participatory Rights Assessment (PRAss) and rights-based development in the Education Sector Support Programme (ESSP), Malawi. Lessons learned so far: a guide to RBD in practice', Consultancy Report, June

Devereux, S. and Maxwell, S. (eds), 2001, Food Security in Sub-Saharan Africa, London: Intermediate Technology Development Group Publishing

DFID, 2000, Realising Human Rights for Poor People, London: Department for International Development

Gaventa, J. and Valderrama, C., 1999, 'Participation, citizenship and local governance', Background note for workshop, June

Goetz, A.-M. and Gaventa, J., 2001, 'Bringing citizen voice and client focus into service delivery', IDS Working Paper 138, Brighton: Institute of Development Studies

Häusermann, J., 1998, A Human Rights Approach to Development, London: Rights and Humanity

Lister, R., 1998, 'Citizen in action: citizenship and community development in Northern Ireland context', Community Development Journal, Vol 33 No 3: 226-35

Moore, M. and Putzel, J., 1999, 'Politics and poverty: a background paper for the World Development Report 2000/1', mimeo, Brighton: Institute of Development Studies
Moser, C., 1998, 'The asset-vulnerability framework: reassessing urban poverty reduction strategies', World Development, Vol 26 No 1: 1-19

Moser, C. and Norton, A., 2001, 'To claim our rights: livelihood security, human rights and sustainable development', Concept Paper, London: Overseas Development Institute

Narayan, D., Chambers, R., Shah, M.K. and Petesch, P., 2000, Voices of the Poor: Crying out for Change, New York: Oxford University Press for the World Bank

Sen, A., 1997, 'Editorial: human capital and human capability', World Development, Vol 25 No 12: 1959-61

Sen, A., 1981, Poverty and Famines: An Essay on Entitlement and Deprivation, Oxford: Clarendon Press

Swift, J., 1989, 'Why are rural people vulnerable to famine?', IDS Bulletin, Vol 20 No 2: 8-15

United Nations, 2003, 'The human rights based approach: towards a common understanding among the UN agencies', draft statement produced at the Second Inter-agency Workshop on Implementing a Human Rights Based Approach in the context of UN Reform, Stamford Connecticut, 5-7 May

UNDP, 2000, Human Rights and Human Development (Human Development Report 2000), United Nations Development Programme, New York and Oxford: Oxford University Press

Webster, N. and Engberg-Pederson, L., 2002, In the Name of the Poor: Contesting Political Space for Poverty Reduction, London: Zed Books

World Bank, 2000, World Development Report 2000/01: Attacking Poverty, Oxford: Oxford University Press 